\title{
Preparation and Spectroscopic Studies of Some Copper and Nickel Schiff Base Complexes and their Applications as Colouring Pigments in Protective Paints Industry
}

\author{
O.A.G. Wahba ${ }^{*}$, A.M. Hassan ${ }^{1}$, A. M. Naser $^{1}$ and A.M. \\ Hanafi $^{2}$ \\ ${ }^{1}$ Chemistry Department, Faculty of Science, Al-Azhar \\ University, Nasr City 11884,and ${ }^{2}$ PACHIN Co., Cairo. Egypt.
}

\begin{abstract}
EW copper (II), nickel (II) Schiff base complexes derived from 3,3-dimethoxybenzidine and selected aldehydes, namely 2,4dihydroxybenzaldehyde with the metal salts have been synthesized using a simple technique of microwave method (Green chemistry). The physical properties of prepared ligand and its metal complexes were recorded. The ligand and complexes were characterized using elemental analysis, NMR, infrared and also their geometrical structure were investigated using spectral UV-Vis reflectance, magnetic susceptibility, electron spin resonance (ESR), thermal gravimetric analysis (TGA) and scan electron microscope (SEM). The performance tests (oil absorption, fineness of grind, moisture content, and $\mathrm{pH}$ and bleeding test in different solvents) of the solid metal complexes were explored to ensure that the complexes can be used as a pigments in the field of anticorrosive paints without any compatibility problems in the paint's vehicle. The anticorrosive paints were formulated based on the prepared metal complexes as a pigments and the Physical, mechanical, colour properties and corrosion resistance of dry paint films were also examined. The obtained results revealed that the prepared metal complex pigments showed excellent mechanical, corrosion resistance with colour stability and did not effect or react with the other components in the anticorrosive paint formula.
\end{abstract}

Keywords: Transition metal complexes, Schiff bases, Pigments, paints, Corrosion resistance.

Coordination compounds of azomethine ligands are important objects of the modern chemistry of metal complexes and are considered in a series of monographs and reviews. An increased attention to complexes of azomethine compounds is due to the possibility of a wide variation of their ligand environment presented by aldehyde and amine moieties and the production of multifunctional materials from these compounds. Among such materials are magneto-active and luminescent complexes [1-3]. The most widespread

*Corresponding author e-mail: Osama_che@yahoo.com

DOI: $1 \quad 0.21608 /$ ejchem. 2017.517.1000

(C) 2017 National Information \& Documentation Center(NIDOC) 
protection of metal materials is the application of organic coatings created from anticorrosion paints. This method secures the chemical or electrochemical reaction of an anticorrosion pigment with a metal alone or with a corrosive agent penetrating through the protective organic coating [4]. Metal complex pigments are mainly used in paints, and the products are fast enough to be applied especially in industrial finishes. In view of this, we described the synthesis and characterization of Schiff base and its copper (II) and nickel (II) complexes. Also, the applications of the prepared complexes as colouring pigments and their corrosion behavior were studied.

\section{Experimental}

\section{Materials and instruments}

All chemicals and solvents used were of BDH and sigma-Aldrich and used without further purification. ${ }^{1}$ HNMR spectra in D6-DMSO with TMS as internal standard were obtained from a Jeol- FX-90Q Fourier NMR spectrometer and the Fourier transform infrared (FT-IR) spectra were recorded on a single-beam spectrometer (Bruker, Vector 22, Germany) with a resolution of $4 \mathrm{~cm}^{-1}$ at the central laboratories of the Egyptian Armed Forces, Egypt. Elemental analys is for carbon, hydrogen and nitrogen were determined by Perkin-Elmer 2400 at the central laboratories of the Egyptian Armed Forces. An Ultra violet spectra (Shimadzu UV-2600/2700), Electron Spin Resonance (ESR, EMX 1444 EPR), Thermal Gravimetric Analysis (TGA, Shimadzu's TGA-50/51) measurements were carried out at Egyptian Atomic Energy Authority. Finally, Scan Electron Microscope (SEM, Quanta 250 FEG) was carried out at the Central Laboratories Sector of Egyptian mineral resources authority.

\section{Preparation of ligand (BDBDA)}

The ligand was prepared by using microwave method [5] in which the 3,3Dimethoxybenzidine \& 2,4- dihydroxybenzaldehyde were mixed in 1:2 molar ratio respectively and grinded very well in agate mortar and transferred to porcelain crucible and then the crucible put in microwave (with suction) for $3-5$ minutes and high yield (98\%) of the N, N'-bis-(2,4-dihydroxybenzaldene)-3,3Dimethoxybenzidine (BDBDA) ligand was obtained with the chemical formula $\mathrm{C}_{28} \mathrm{H}_{24} \mathrm{~N}_{2} \mathrm{O}_{6}$ and chemical structure as shown in Scheme 1.

\section{Preparation of solid complexes, and their evaluation as pigments}

All the complexes were prepared by mixing equal molar ratio amounts of ligand BDBDA and the hydrated metal(II) acetate tetra[M $\left.\left.=\mathrm{Cu}^{\mathrm{II}}, \mathrm{Ni}^{\mathrm{II}}\right)\right]$ in porcelain crucible without grinding, then the crucible put in the microwave for 5-7 min and the resulting complexes (Fig.1\&2) were removed from microwave and cooled. 
Evaluation of the prepared complexes as pigments

The prepared complexes were evaluated as pigments and the following tests were performed according the standard test methods of the American society of testing and materials (ASTM):(a) oil absorption (ASTM D:281-95, 1995) (b) hydrogen ion concentration (pH value) (A STM D:1583-01, 2001), (c) bleed test (ASTM D:279-87, 1997), (d) fineness of dispersion (ASTM D:1210-96, 1996), (e) Moisture content (ASTM D:280-95, 1995).

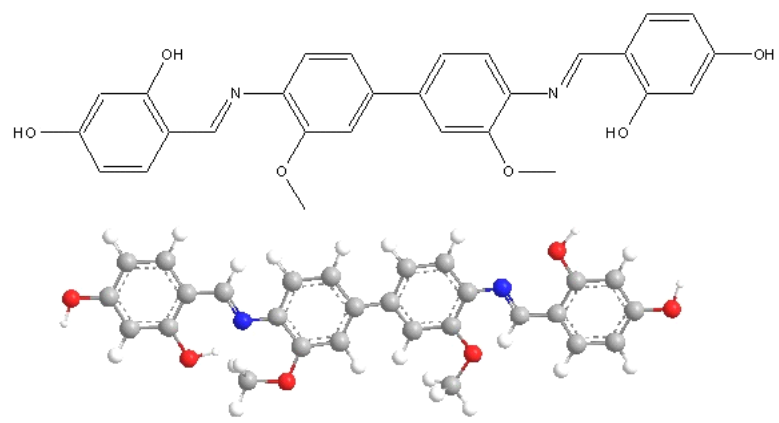

Scheme 1. The chemical structure of ligand DBDBA.
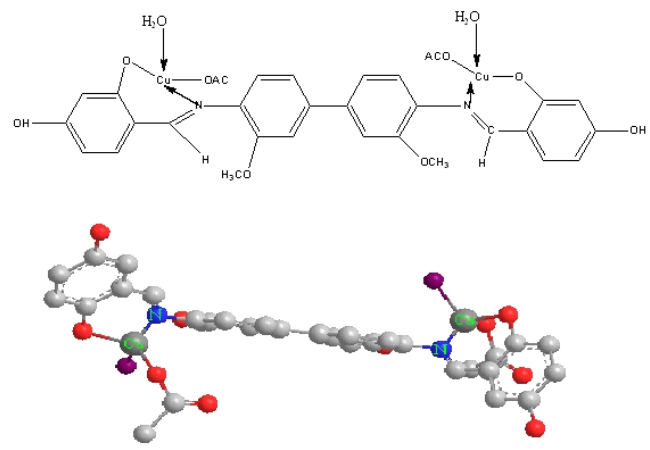

Fig. 1. The proposed Structure of $\mathrm{Cu}-\mathrm{BDBDA}$ complex. 

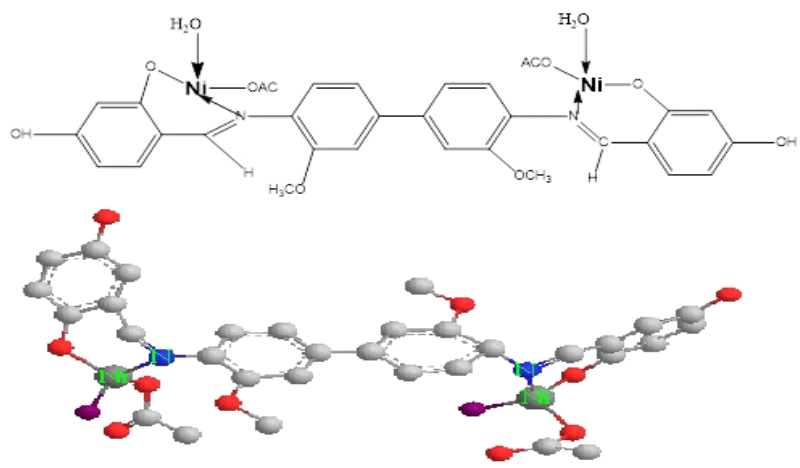

Fig. 2. The proposed Structure of Ni-BDBDA complex.

Paint preparation, evaluation and application

The paints were prepared by employing high stirring mixer and then they were introduced into a cold roll mild steel panels by using spray gun in a closed cabinet to give a dry paint film. The pigment is formu lated in anticorrosion paint formula based on epoxy resin as anticorrosive binder according to conditions stated in Table 1.

TABLE 1. Anticorrosion paint formula.

\begin{tabular}{lc}
\hline \multicolumn{1}{c}{ Ingredients } & Conc. (\%) \\
\hline${ }^{(1)}$ Epoxy resin & 25.5 \\
Silanol functional silicone resin & 0.2 \\
(dispersing agent) & 6 \\
$\mathrm{~N}-$ Butanol & 20 \\
Aluminum silicate & 13 \\
$\mathrm{Mg}_{3} \mathrm{Si}_{4} \mathrm{O}_{10}(\mathrm{OH})_{2}$ (talc powder) & 12 \\
$\mathrm{BaSO}_{4}$ & 5 \\
Prepared complex & 2 \\
Xylene & 2 \\
Fumed silica & 0.7 \\
Organic clay & 0.1 \\
Polymethyl siloxane (antifoaming agent) & 0.2 \\
Polyether copolymers (leveling agent) & 13.3 \\
Methyl ethyl ketone & 12.5 \\
Curing agent (poly amide) &
\end{tabular}

(1) Epoxide Equivalent Weight (g/eq): 430, Density @ $25^{\circ} \mathrm{C}(\mathrm{g} / \mathrm{ml}): 1.09$, Non-volatile Content (wt\%): 74-76.

Various methods have been applied for testing and evaluation of the prepared paints as follows:

Egypt. J. Chem. 60, No. 1 (2017) 


\section{Physical and mechanical tests}

A variety of physical and mechanical evaluations of the paint films were carried out on prepared steel panels [A STM D 609-00] such as (a) determination of the dry paint film thickness [ASTM D 4138-07, 2007]; (b) measuring of adhesion using adhesive tape [ASTM D 3359-97, 2005]; (c) resistance of organic coatings to the effects of rapid deformation (impact) [ASTM D 2794-93 (Reapproved 1999)].

\section{Corrosion tests}

The coated steel panels were put in a salt spray cabinet at a temperature of $35^{\circ} \mathrm{C}$, a mo isture of $100 \%$ and a test solution of $5 \% \mathrm{NaCl}$ concentration for $500 \mathrm{~h}$ [ASTM D: B117-03]. The films were then examined for any defects such as rusting [ASTM D 6294-98, 2007], blistering [ASTM D 714-07, 2007], and scribe failure [A STM D1654 -08]. Photographic inspection and grading of the paint films according to standard methods were carried out at the end of the test for a completion of corrosion resistance measurements (Fig. 8). A cross lines in the middle of each panel was made using a cutter to permit the salt solution to penetrate the panel to examine adherence of paint over the painted area.

\section{Determination of chromatic characteristics}

The chromatic characteristics of a substance are defined by the colorimetric or chromaticity coordinates: clarity $\left(\mathrm{L}^{*}\right)$, red/green colour component $\left(\mathrm{a}^{*}\right)$, and blue/yellow colour component ( $\left.\mathrm{b}^{*}\right)$; and by its derived magnitudes: chroma $\left(\mathrm{C}^{*}\right)$, tone $\left(\mathrm{H}^{*}\right)$ and chromacity $\left[\left(\mathrm{a}^{*}, \mathrm{~b}^{*}\right)\right.$ or $\left.\left(\mathrm{C}^{*}, \mathrm{H}^{*}\right)\right]$, Overall colorimetric difference between two samples $\Delta \mathrm{E}^{*}$ is defined according to the following mathematical functions:

The colour measurements were obtained by using the X-Rite RM200QC instrument, which is Imaging Spectro-colorimeter bridges for the gap between colour appearance and material colour. The device is automatically measuring the above mentioned parameters $\left(\Delta \mathrm{E}^{*}, \Delta \mathrm{L}^{*}, \Delta \mathrm{a}^{*}, \Delta \mathrm{b}^{*}, \Delta \mathrm{C}^{*}\right)[6]$.

\section{Results and Discussion}

All the analytical, physical and spectroscopic data of the Schiff bases and their isolated metal complexes are given in Tables 2 and 3. The complexes are air stable for a long time and are soluble in DMF \& DMSO.

\section{Infra-red spectra \\ Infrared spectra of ligand}

The positions of the significant IR bands of $\mathrm{N}, \mathrm{N}^{\prime}$ bis $(2,4-$ dihydroxybenzaldehyde)-3,3 Dimethoxyanizidine (BDBDA) and their metal comple xes are summarized in Table 3. The IR spectra of BDBDA show a strong band at $1621 \mathrm{~cm}^{-1}$ assignable to $\mathrm{v}(\mathrm{C}=\mathrm{N})$ of the azo methine. The observation of this band confirms the formation of the azo methine linkage. The ligand also has 
a strong band in the region 787-844 $\mathrm{cm}^{-1}$ corresponding to the out-of-plane deformation of the aromatic rings. The observation of broad weak bands in the $2600-3500 \mathrm{~cm}^{-1}$ region BDBDA ligand is taken as an evidence for the existence of intermolecular hydrogen bonding of the type $\mathrm{OH}$.... $[7,8]$.

$\mathrm{Cu}$ II and $\mathrm{Ni}{ }^{I I}$ complexes

The IR spectral data (Table 3) of these complexes indicates that the ligand BDBDA behaves in a tetradentate manner with two $\mathrm{Cu}{ }^{\mathrm{II}}$ ions and two $\mathrm{Ni}^{\mathrm{II}}$ ions, respectively through azomethine and deprotonating $\mathrm{OH}$ groups. This behavior is supported on the bas is of the following evidences (i) the bands due to $v(\mathrm{OH})$ and $\delta(\mathrm{OH})$ of the ligand BDBDA have decreased in their intensity with a red shift, indicating the deprotonating of $\mathrm{OH}$ groups for BDBDA (ii) the shift observed in the $v(\mathrm{C}-\mathrm{O})$ frequency (iii) the negative shift of the azomethine group to lower wavenumber suggesting the involvement of this group in bonding (iv) the splitting of $v(C=N)$ of BDBDA complexes suggests the presence of two types of azo methine groups. The two bands observed at 1543, $1437 \mathrm{~cm}^{-1}$ and 1580,1436 $\mathrm{cm}^{-1}$ attributed to $v_{\mathrm{as}}$ and $v_{\mathrm{s}}$ carboxylic modes of $\mathrm{Cu}$ and $\mathrm{Ni}$ complexes respectively, elucidate the presence of acetate ion in the proposed structures in Fig. 1[9-11].

\section{${ }^{1} H$ NMR spectra of ligand}

The ${ }^{1}$ HNMR spectra of the ligand were recorded in DMSO (Figure 3). The proton NMR spectrum data of the ligand as shown in Table 2 indicates the appearance of a singlet signal in the range of $3.94-3.99 \mathrm{ppm}$ due to the presence methyl protons. In the aromatic region; a few doublets and some overlapping doublets/multiplet are observed at range $6.2-7.5 \mathrm{ppm}$. These signals are due to the protons of benzene rings. The signals due to azomethine protons $(-\mathrm{CH}=\mathrm{N}-)$ appeared as a singlet at $8.85 \mathrm{ppm}$. Another singlet corresponding to one proton is observed in the range $14.3 \mathrm{ppm}$ is due to phenolic-OH group [12].

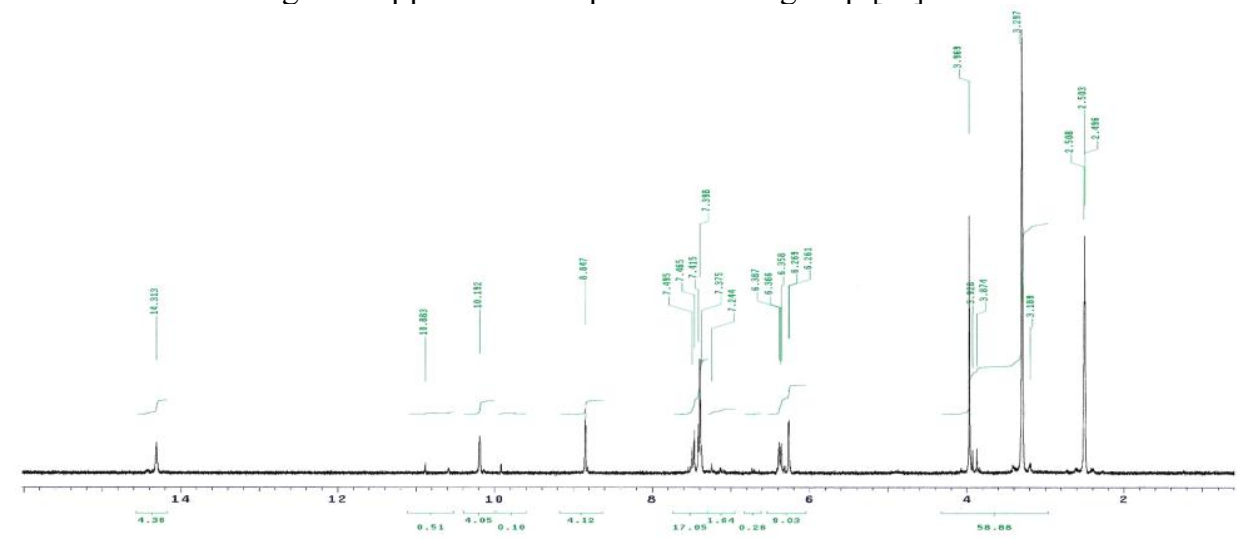

Fig. 3. The ${ }^{1}$ HNMR spectroscopy of Ligand (BDBDA). 
$U V$-Visible reflectance and Magnetic properties

The electronic spectra data of BDBDA in Table 3 showed the bands that observed at 375 and $412 \mathrm{~nm}$ which are assigned to the $\pi \rightarrow \pi^{*}$ and $\mathrm{n} \rightarrow \pi^{*}$ transitions of the ligand respectively. The electronic spectra data of $\mathrm{Cu}$ (II) complex in Table 3 (Fig. 7) exhibit two bands at $676 \mathrm{~nm}$ and $339 \mathrm{~nm}(\mathrm{Cu}-$ BDBDA Transitions) due to the $2 \mathrm{~B} 1 \mathrm{~g} \rightarrow 2 \mathrm{Eg}, \mathrm{L} \rightarrow \mathrm{M}(\mathrm{C} . \mathrm{T})$ transitions, and magnetic data shows $\mu$ eff value 2.19 B.M corresponding to the presence of one unpaired of electron which is consistent with tetrahedral geometry.

The $\mu$ eff value 2.94 B.M obtained for the NiII complex is in good agreement with the tetrahedral geometry and the electronic spectra of Nickel complex in Table 3 , appears two bands may be assigned to $d-d$ transition which exhibit in the range of $(460 \mathrm{~nm})$ and $(373 \mathrm{~nm})$. These bands may be assigned to the two spin-allowed transitions $1 \mathrm{~A} 1 \mathrm{~g}(\mathrm{D}) \rightarrow 1 \mathrm{~A} 2 \mathrm{~g}(\mathrm{G})(\mathrm{v})$, and $1 \mathrm{~A} 1 \mathrm{~g}(\mathrm{D}) \rightarrow 1 \mathrm{~B} 2 \mathrm{~g}(\mathrm{G})$ (v2) respectively [13-16].

TABLE 2. Analytical, physical and spectroscopic data of the Schiff base ligand and its related metal complexes.

\begin{tabular}{|c|c|c|c|c|}
\hline Compound & $\begin{array}{l}\text { M.p }\left({ }^{\circ} \mathbf{C}\right), \\
\text { colour }\end{array}$ & $\begin{array}{l}\text { Theoretical } \\
\text { (found) } \% \\
\text { C N } \mathrm{H}\end{array}$ & $\begin{array}{c}\text { 1H NMR } \\
\text { Chemical } \\
\text { Shift ( } \delta \text { p.p.m.) }\end{array}$ & $\begin{array}{c}\text { ESR } \\
\text { Parameters }\end{array}$ \\
\hline Ligand (BDBDA) & $\begin{array}{l}315, \\
\text { Orange }\end{array}$ & $\begin{array}{c}69 \\
5 \\
5.8 \\
(68) \\
(5.18) \\
(5.7)\end{array}$ & $\begin{array}{c}14.3(\mathrm{OH}) \\
8.85 \\
(\mathrm{CH}=\mathrm{N}, \mathrm{s}, 2 \mathrm{H}) \\
3.9\left(\mathrm{OCH}_{3}\right) \\
6.2-7.5 \\
\text { (ring,m,18H) }\end{array}$ & $\begin{array}{l}\mathrm{g}_{/ /}(2.11) \\
\mathrm{g} \perp(2.19)\end{array}$ \\
\hline $\begin{array}{c}{\left[\mathrm{Cu}_{2}(\mathrm{BDBDA}-2 \mathrm{H})\right.} \\
\left.(\mathrm{OAC})_{2}\left(\mathrm{H}_{2} \mathrm{O}\right)_{2}\right]\end{array}$ & $\begin{array}{l}>370, \\
\text { Yellowish } \\
\text { Brown }\end{array}$ & $\begin{array}{c}50.3 \\
3.7 \\
4.2 \\
(50.5) \\
(3.7) \\
(4.9)\end{array}$ & & \\
\hline $\begin{array}{c}{\left[\mathrm{Ni}_{2}(\mathrm{BDBDA}-\right.} \\
\left.2 \mathrm{H})(\mathrm{OAC})_{3}\left(\mathrm{H}_{2} \mathrm{O}\right)_{2}\right]\end{array}$ & $\begin{array}{l}>370 \\
\text { Yellow }\end{array}$ & $\begin{array}{c}50 \\
3.5 \\
4 . \\
(48) \\
(3.6) \\
(5)\end{array}$ & & \\
\hline
\end{tabular}


TABLE 3. Significant I.R, UV-Reflectance and magnetic data of Schiff base ligand and its metal complexes.

\begin{tabular}{|c|c|c|c|c|c|c|c|c|c|c|}
\hline \multirow{2}{*}{$\begin{array}{c}\text { Compound } \\
\text { Ligand (BDBDA) }\end{array}$} & \multicolumn{8}{|c|}{$v(\mathrm{OH}) v(\mathrm{C}=\mathrm{N}) \delta(\mathrm{OH}) v(\mathrm{C}-\mathrm{O}) \mathrm{v}(\mathrm{M}-\mathrm{O}) v(\mathrm{M}-\mathrm{N}) \mathrm{v}(\mathrm{OAC})_{\mathrm{Vas},} \mathrm{v}(\mathrm{OAC})_{\mathrm{Vs}}$} & \multirow{2}{*}{$\begin{array}{c}\begin{array}{c}\text { (B.Max }, \mathbf{n m} \\
\text { (assignments) }\end{array} \\
375\left(\pi \rightarrow \pi^{*}\right), \\
412\left(\mathrm{n} \rightarrow \pi^{*}\right)\end{array}$} & \multirow[t]{2}{*}{$\mu$ eff. } \\
\hline & 3500 & 1621 & 1320 & 1020 & - & - & - & - & & \\
\hline $\begin{array}{c}{\left[\mathrm{Cu}_{2}(\mathrm{BDBDA}-\right.} \\
\left.2 \mathrm{H})(\mathrm{OAC})_{2}\left(\mathrm{H}_{2} \mathrm{O}\right)_{2}\right]\end{array}$ & 3478 & 1616 & 1338 & 1261 & 490 & 309 & 1437 & 1543 & $\begin{array}{c}676 \mathrm{~L} \rightarrow \mathrm{M}(\mathrm{C} . \mathrm{T}) \\
339\left({ }^{2} \mathrm{~B}_{2} \rightarrow{ }^{2} \mathrm{Eg}\right)\end{array}$ & 2.19 \\
\hline $\begin{array}{c}{\left[\mathrm{Ni}_{2}(\text { BDBDA- }\right.} \\
\left.2 \mathrm{H})(\mathrm{OAC})_{3}\left(\mathrm{H}_{2} \mathrm{O}\right)_{2}\right]\end{array}$ & 3308 & 1595 & 1227 & 1191 & 617,501 & 312 & 1436 & 1580 & $\begin{array}{c}460\left({ }^{1} \mathrm{~A}_{1 \mathrm{~g}}(\mathrm{D}) \rightarrow^{1} \mathrm{~A}_{2 \mathrm{gg}}(\mathrm{G})\right. \\
373\left({ }^{1} \mathrm{~A}_{1 \mathrm{gg}}(\mathrm{D}) \rightarrow{ }^{1} \mathrm{~B}_{2 \mathrm{~g}}(\mathrm{G})\right. \\
\left(\mathrm{V}_{2}\right)\end{array}$ & 2.94 \\
\hline
\end{tabular}

Thermal studies

Thermal Analysis of all complexes was carried out by the TGA, DTA techniques. The experimental results revealed that the degradation occurred in multiple stages, following a complex mechanism. For each stage, the kinetic parameters and thermogravimetric characterization have been estimated. The thermal behavior of all complexes explains as followed: the TG curves follows the decrease in sample mass with an increase in temperature. In the present investigation, heating rates were suitably controlled at $10{ }^{\circ} \mathrm{C} /$ minute and mass loss followed up to $25-1000{ }^{\circ} \mathrm{C}$. The copper complex slowly studied the decomposition between 240 and $480{ }^{\circ} \mathrm{C}$ (Fig. 4). The first mass loss occurring at temperature $>240{ }^{\circ} \mathrm{C}$ attributed to the removal of coordinated $\mathrm{H}_{2} \mathrm{O}$ and the acetate molecules, the mass loss occurring at temp $240-340^{\circ} \mathrm{C}$ correspond to the decomposition of part of organic ligand, then mass loss at temp 340-480 is attributed to the decomposition of the residue part of ligand molecules. The final product of the thermal decomposition at $480-1000{ }^{\circ} \mathrm{C}$ might be referring to the presence of metal oxide [17].

On the other hand, the nickel complex studied the decomposition between 150 and $382{ }^{\circ} \mathrm{C}$ (Fig. 5). The first mass loss occurring at temperature $300{ }^{\circ} \mathrm{C}$ attributed to the removal of crystalline and coordinated $\mathrm{H}_{2} \mathrm{O}$ and the acetate molecules in the complex meanwhile the mass loss occurring at temp $300-$ $382^{\circ} \mathrm{C}$ correspond to the decomposition of organic ligand molecules. The final product of the thermal decomposition at $382-1000{ }^{\circ} \mathrm{C}$ might be referring to the presence of metal oxide [18]. 


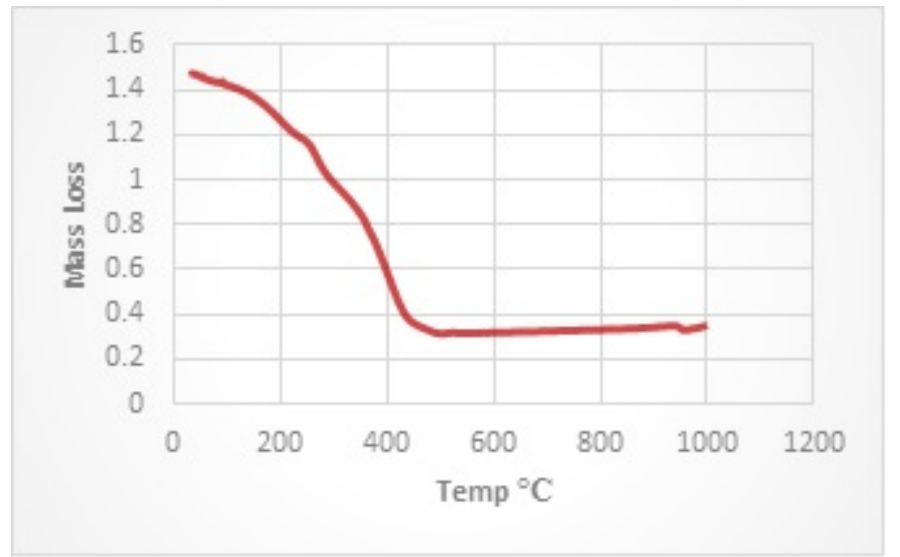

Fig. 4. Thermal gravimetric analysis $\mathrm{Cu}$-BDBDA.

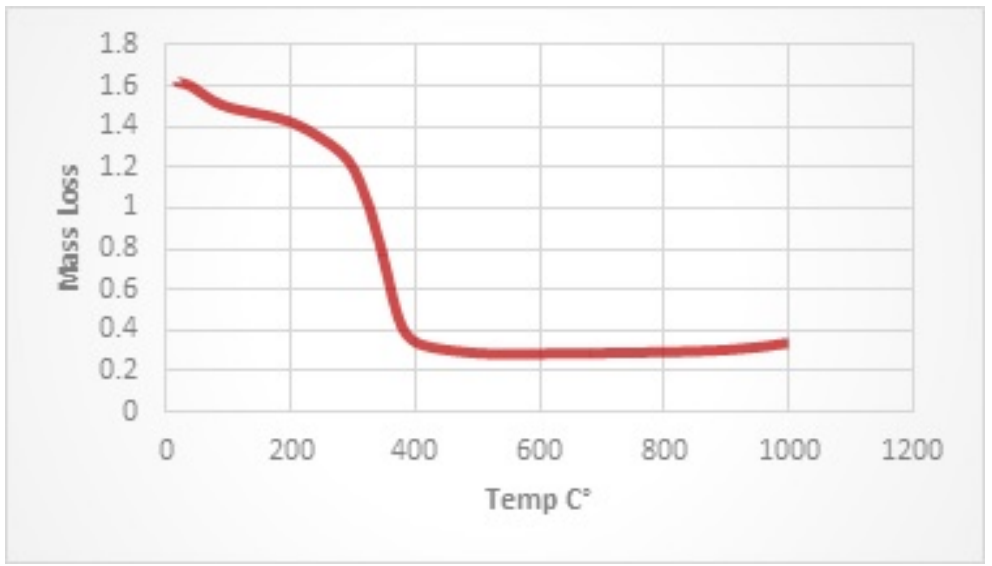

Fig. 5. Thermal gravimetric analysis Ni-BDBDA

Electron Spin Resonance (ESR)

ESR spectra of powdered sample of [Cu-BDBDA] exhibits an axial signal with two g values at $298 \mathrm{~K}$, (Table 2, Fig. 6). The axial signals were analysed by the procedure given by Hathaway and Billing. The $\mathrm{g}_{/ /}$and $\mathrm{g} \perp$ values (table 2 ) are $>2.04$, consistent with copper (II) in axial symmetry with all the principle 
axes aligned parallel. These $g$ values indicate a tetrahedral stereochemistry. On the other hand, the calculated $\mathrm{G}$ value for the $\mathrm{Cu}^{\mathrm{II}}-\mathrm{L}$ is lesser than 4 , indicates the exchange interaction between the copper centres $[19,20]$.

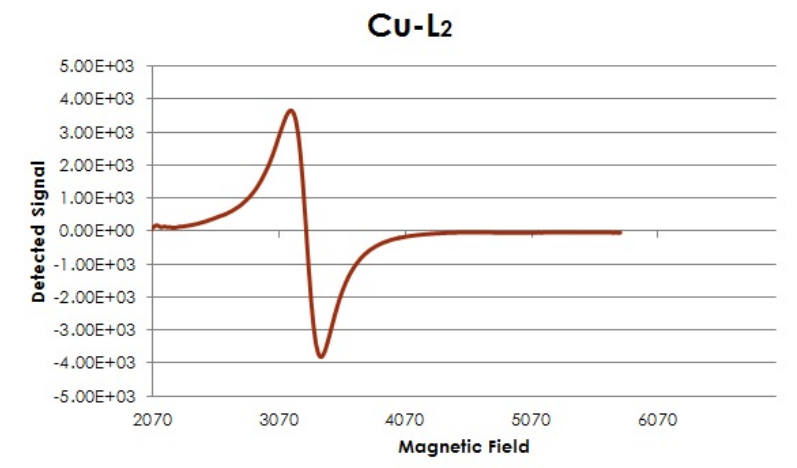

Fig. 6. ES R spectra at copper (II) complex at $298 \mathrm{k}$ in the solid state.

\section{Scanning Electron Microscopy}

The morphology of the copper complex is performed with SEM and Fig. 7 shows that $\mathrm{Cu}$-BDBDA which appear as bacillus shape with diameter width (80$90 \mathrm{~nm}$ ) and bacillus particles are aggregated together to form amorphous shape with no porous structure which explain the lower values of oil absorption. These bacillus particles provide a reinforcing effect reducing the water and gas permeability and therefore imparted good anticorrosive properties and special appearance to the paint film when used in paint formulations.

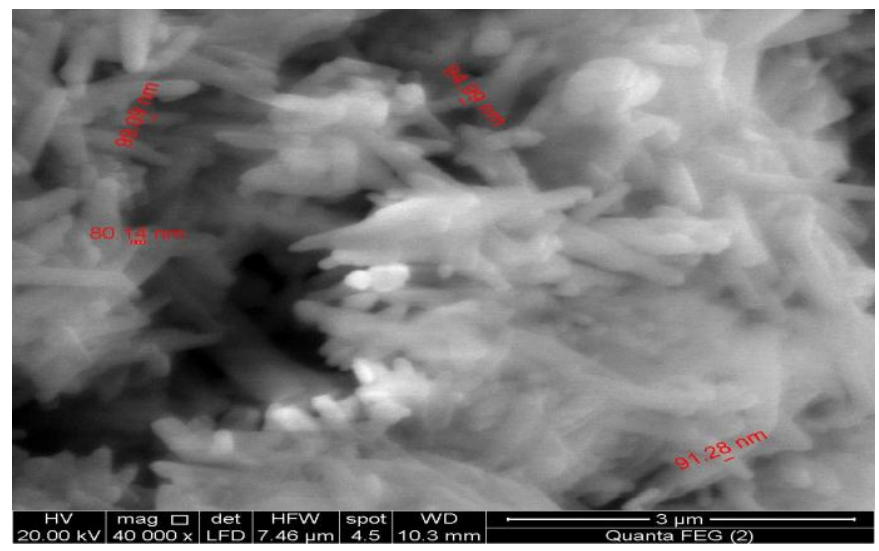

Fig .7. SEM photo of the copper complex Cu-BDBDA. 


\section{Evaluation of the prepared complexes as pigments for paint application.}

Physical properties of the prepared complexes

The prepared complexes are evaluated as pigments before using in the corrosion resistance paints formu lations and the following test methods (Table 4) cover the procedures for determining certain properties of pig ments according to ASTM Standards.

Based on the results summarized in Table 4, it was noticed that all the synthesized complexes are alkaline in nature according to $\mathrm{pH}$ values. It is clear that the oil absorption values of $\mathrm{Cu}$-BDBDA complex were the highest among the group, whereas Ni-BDBDA complex was the lowest. As the oil absorption value increased, more binder is needed to completely wet the pig ment and form a homogeneous paint film and vice versa.

The moisture contents in all samples are neglectable which is referring to the stability of the complexes for the storage for long time and don't effect on their compatibility with the paint media. The fineness (degree of dispersion) test covers the measurement of the degree of dispersion (commonly referred to as "fineness of grind") of the pigment in a pigment-vehicle system such as liquid coatings and their intermediates., The fineness results of the samples indicated that all prepared complexes are highly dispersed in pigment-vehicle. The bleeding test determines the amount of colour produced when the pigment is in direct contact with different solvents. The bleeding tests implying a high degree of stability of the prepared pigments. Moreover, the bleeding results indicated that there is no bleeding (none perceptible colour)[21].

TABLE 4. The results of performance tests for the prepared complexes as pigments.

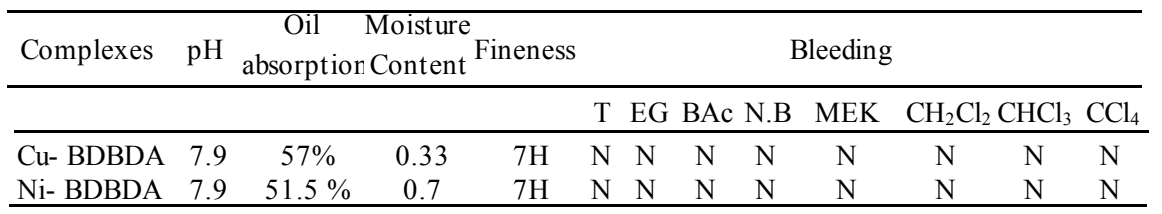

$[\mathrm{H}=$ Hegman (fineness unite), $\mathrm{T}=$ Toluene, $\mathrm{EG}=$ Ethylene Glycol, $\mathrm{BAc}=$ Butyl Acetate, N.B=Normal Butanol, MEK=Methyl Ethyl Ketone, $\mathrm{N}=$ None.]

\section{Physical and mechanical properties of the painted films}

Based on the results of the physical and mechanical properties of dry paint films with \& without prepared complexes given in table 5, the prepared films exhibit high film performance when the coating of $120 \mu \mathrm{m}$ thickness was applied to the surface. Physical and mechanical properties of the coating composition were not affected by the different prepared complexes. 
TABLE 5. Results of Impact, Dry film thickness and Adhesion for painted films based on the prepared complexes.

\begin{tabular}{cccc}
\hline Compounds & Impact & Dry Film Thickness & Adhesion \\
\hline Blank Sample & Pass & $120 \mu \mathrm{m}$ & $5 \mathrm{~A}$ \\
Cu- BDBDA & Pass & $120 \mu \mathrm{m}$ & $5 \mathrm{~A}$ \\
Ni- BDBDA & Pass & $120 \mu \mathrm{m}$ & $5 \mathrm{~A}$ \\
\hline
\end{tabular}

Corrosion resistance of the painted films

Anticorrosive protection by paints has recently been described as being a combination of a physical barrier, a chemical inhibitor, and an electrical resistor. Pigments are incorporated in paints in order to enhance the barrier effect and give the desired color with no effect on the properties of paint's film. In the current work the corrosion properties of the paints based on the prepared complexes were studied to investigate if there is any effect of the prepared complex on the paint's film.

The results of corrosion resistance of the blank film and the painted films based on the prepared Complexes are given in Table 6 and Fig. 8 shows the photo of the painted films after salt spray test.The film thickness of the films ranges from $100 \mu \mathrm{m}$ to $120 \mu \mathrm{m}$.

The blistering size is graded from 10 to 0 , where 10 represents of no blistering and 0 representatives of the largest blister. Blistering frequency is denoted by F, M, MD and D (few, medium, medium dense and dense). Painted, or coated, specimens subjected to a corrosive environment are also evaluated by recording the average (mean) maximum and minimum creep age from the scribe mark. Scribe failure is also rated on a scale from 10 to 0 , with 10 being zero $(\mathrm{mm})$ from the scribe mark and 0 is $16(\mathrm{~mm})$ from the scribe mark. Rust grade 10 represents no rusting or less than $0.01 \%$ of surface rusted; rust grade 0 represents approximately $100 \%$ of surface rusted.

TABLE 6. Results of corrosion resistance of painted films based on the prepared complexes.

\begin{tabular}{cccccc}
\hline Painted film & \multicolumn{2}{c}{ Blistering } & \multicolumn{4}{c}{ Scrub failure(mm) } & Rust grad \\
\cline { 2 - 6 } Blank Sample & \multirow{2}{*}{ Size } & Frequency & $\begin{array}{c}\text { Area Failed } \\
\text { \% }\end{array}$ & $\begin{array}{c}\text { Rating } \\
\text { Number }\end{array}$ & \\
\cline { 2 - 6 } & 9 & F & 1 & 9 & 9 \\
Cu- BDBDA & 7 & MD & 2 & 7 & 9 \\
Ni- BDBDA & 8 & F & 1 & 9 & 9 \\
\hline
\end{tabular}

\section{Chromatic characteristics of painted films}

The results of colour characteristics of the painted films based on the prepared complexes before and after salt spray test are listed in Table 7. The results shows that the $\Delta \mathrm{E}$ values for the painted films after salt spray test were

Egypt. J. Chem. 60, No. 1 (2017) 
less than one, which indicates no change in the colour of the films before and after exposure to the corrosion conditions which is referring to the colour stability of the painted films, hence explains the stability of the prepared complexes when they used as anticorrosive metal complex pigments.

TABLE 7. Results of chromaticity coordinates of painted films before and after salt spray test.

\begin{tabular}{|c|c|c|c|c|c|c|c|c|c|c|}
\hline \multirow[t]{2}{*}{ Complex } & \multicolumn{5}{|c|}{ Before salt spray test } & \multicolumn{5}{|c|}{ After salt spray test } \\
\hline & $\mathbf{L}^{*}$ & $\mathbf{a}^{*}$ & $\mathbf{b}^{*}$ & $\mathbf{C}^{*}$ & $\mathbf{h}$ & $\mathbf{L}^{*}$ & $\mathbf{a}^{*}$ & $\mathbf{b}^{*}$ & $\mathbf{h}$ & $\Delta \mathbf{E}$ \\
\hline Cu- BDBDA & 78.9 & 8.8 & 35.4 & 36.5 & 76 & 78.5 & 8.9 & 35.2 & 75.8 & 0.7 \\
\hline Ni- BDBDA & 71.2 & 16.9 & 81.1 & 82.9 & 79.9 & 71.2 & 16.7 & 80.8 & 79.9 & 0.8 \\
\hline
\end{tabular}
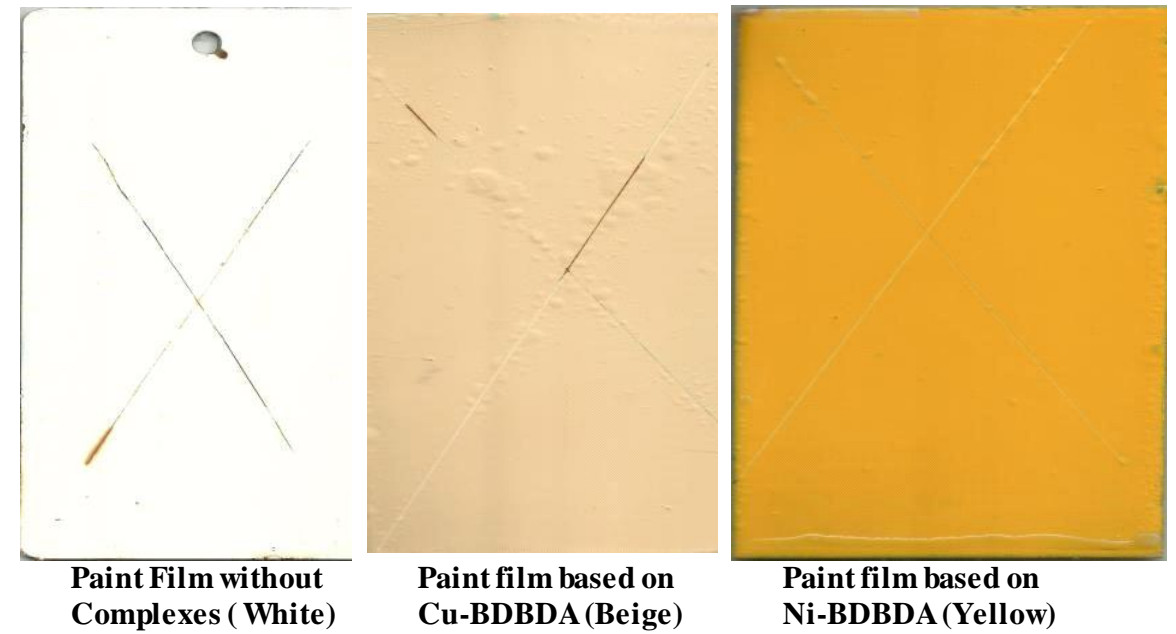

Complexes (White)

Cu-BDBDA (Beige)

Paint film based on

Ni-BDBDA(Yellow)

Fig. 8. Photographic of the painted films with and without the prepared complexes after salt spray test.

\section{Conclusion}

- The organic ligands and their metal complexes were successfully prepared by microwave method (Green Chemistry) and high yield is obtained.

- The physical properties of the prepared complexes (Fineness, Moisture content, bleeding), signified good performance materials.

- The prepared metal complexes can be used as pigments in the field of anticorrosion paints with no side effects on the paint formula.

- The Paint films based on the prepared complexes exhibited good mechanical properties (impact, adhesion).

- The Paint films based on the prepared complexes exhibited good corrosion resis tance properties. 
- There was no difference in the color properties of the painted films before and after corrosion conditions which is referring to the stability of the color of the prepared complexes.

\section{References}

1. Vigato, P.A., Tamburini,S. and Bertelo, .L., The development of compartmental macrocyclic Schiff bases and related polyamine derivatives. Coordination. Chem. Rev, 251, 1311-1492 (2007).

2. Garnovskiiand, A.D. and Vasil'chenko, I.S., Rational design of metal coordination compounds with azomethine ligands. Uspekhi.. Khimii, 71, 10641089 (2002).

3. Kharissov, B. I. and Garnovskii, A.D., Synthetic Coordination and Organometallic Chemistry, New York: Marcel Dekker, pp. 513. (2003).

4. Benda, P. and Kalendová, A., Anticorrosion Properties of Pigments based on Ferrite Coated Zinc Particles. Phys. Procedia, 44, 185-194 (2013)

5. Safari, N., Jamaat, P., Pirouzmand, M. and Shaabani, A., Synthesis of Metallophthalocyanines under Solvent-free Conditions using Microwave Irradiation. J. Porphyrins. Phthalocyanines, 8, 1209- 1213 (2004).

6. The International Organization for Standardization (ISO), ISO (11664-4: 2008).

7. Azzouz, A.S.P. and AL-Dabagh, A. B. N., The UV and IR spectra of Some Schiff bases derived from salicylaldehyde and O-methoxybenzaldehyde. Study the influence of concentration of Schiff base on tautomerism reaction process. Natl. J. Chem, 32, 677- 686 (2008).

8. Ziolek, M, Kubicki, J, Maciejewski, A, Naskrecki, R. and Grabowska, A., Excited state proton transfer and photochromism of an aromatic Schiff base. Pico- and femtosecond kinetics of the $N, N^{\prime}$-bis(salicylidene)-p-phenylenediamine (BSP). Chem. Phys. Letters, 369, 80-89 (2003)

9. Pulimamidi, R., Lakshmi, P. and Jayatyaga, V., Synthesis and Structural Studies of First Row Transition Metal Complexes with Pentadentate ONNNO Donor Schiff Base derived from 5- Acetyl 2,4 - Dihydroxy Acetophenone and DiethyleneTriamine. International. J. ChemTech. Research, 2, 1494- 1500 (2010).

10. Debnath, A., Hussain, F. and Masram, D.T., Synthesis, Characterization, and Antifungal Studies of Cr (III) Complex of Norfloxacin and Bipiridyl Ligand. Bioinorg. Chem. Applications, 1, 96-102 (2014).

11. Yahyazadeh, A. and Azimi, V., Synthesis of some unsymmetrical new Schiff bases from azo dyes. European. Chem. Bulletin, 2, 453-455 (2013) 
12. Figgis, B. and Hitchman, M., Ligand Field Theory and its Applications, New York: Wiley-VCH, pp.354.(2000).

13. Chandra, S. and Gupta, L. K., EPR and electronic spectral studies on Co(II), Ni(II) and $\mathrm{Cu}(\mathrm{II})$ complexes with a new tetradentate [N4] macrocyclic ligand and their biological activity. Spectro Chimica Acta., 60, 1563-1571 (2004).

14. Simgh, N. and Simgh, S., Complexes of 1-isonicotinoyl-4-benzoyl-3thiosemicarbazide with manganese(II), iron(III), chromium(III), cobalt(II), nickel(II), copper(II) and zinc(II).” Transition Metal Chem, 26, 487-495 (2001).

15. Athar, F., Arjmand, F. and Tabssum, S., New asymmetric $\mathrm{N}_{2} \mathrm{~S}_{2}$ macrocy cles, their metal chelates and the photokinetics of DNA-complex interaction. Transition Metal Chem, 26, 426-429 (2001).

16. Lever, A., Inorganic Electronic Spectroscopy, $1^{\text {st }}$ ed, Amsterdam: Elsevier, pp. 249255. (1968).

17. Lever, A., Inorganic Electronic Spectroscopy, $2^{\text {nd }}$ ed, Amsterdam: Elsevier, pp. 480505. (1984).

18. Mangamamba, T., Ganorkar, M.C. and Swarnabala, G., Characterization of Complexes Synthesized Using Schiff Base Ligands and Their Screening for Toxicity Two Fungal and One Bacterial Species on Rice Pathogens. International. J. Inorganic Chem, 2014,1-22 ( 2014)

19. MacDonald, L.G., Brown, D.H. and Smith, W.E., the electron spin resonance of copper(II) schiff base complexes containing amino acids as part of the ligand. Inorganica Chimica Acta, 63, 213-216 (1982).

20. Mruthyunjayaswamy, B.H.M., Nagesh, G.Y., Ramesh, M., Priyanka, B. and Heena B., Synthesis, characterization and antioxidant activity of Schiff base ligand and its metal complexes containing thiazole moiety. Der. Pharma Chemica., 7, 556$562(2015)$

21. Fouad O. A, Hassan A. M, Abd El-Wahab, H, Mohy Eldin, Naser A. M. and Wahba, O. G., Synthesis, characterization and application of some nanosized mixed metal oxides as high heat resistant pigments: $\mathrm{Ca}_{2} \mathrm{CuO}_{3}, \mathrm{Ca}_{3} \mathrm{Co}_{2} \mathrm{O}_{6}$, and $\mathrm{NiSb}_{2} \mathrm{O}_{6}$. J. Alloys. Compounds, 537, 165-170 (2012). 


\title{
تحضير و دراسات طيفيه لبعض متر اكبات قواعد شيف المعقده

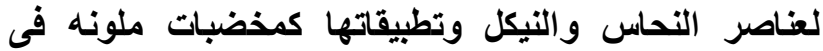 \\ صناعه د هانات الحمايه
}

\author{
أسامة وهبه 1'، علي مصطفي حسن 1، عبد الرحمن ناصر 1 و و عادل حنفي² \\ 1قسم الكيمياء _كلية العلوم - جامعة الأزهرو 2شركة باكين للاهاناتـ القاهرة - مصر.
}

يهدف هذا البحث الى تحضير وتوصيف مركبات معقده تحتوى على عناصر

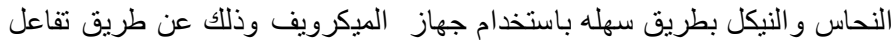

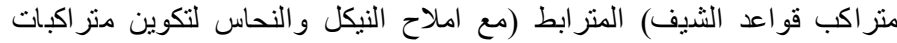

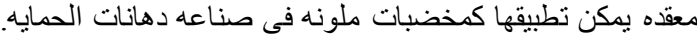

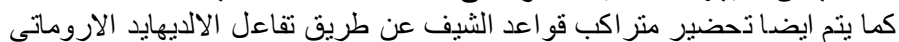

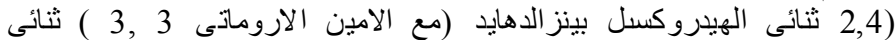

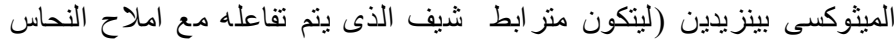

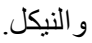
• ثم يتم قياس الخواص الفيزيائيه والتركيب الجزيئى لجميع المركبات التى تم

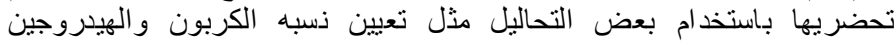

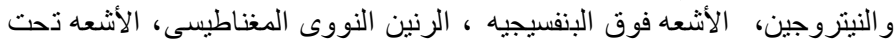

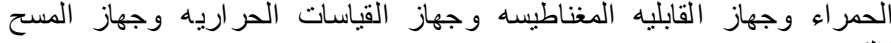

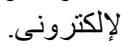

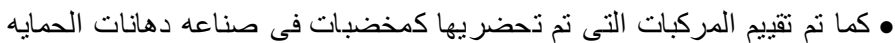

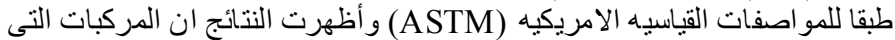

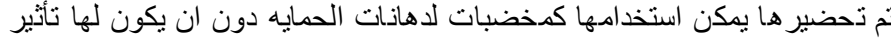

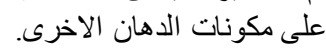

